\title{
PROFESSIONAL SOCIAL WORKERS IN THE ERA OF REVOLUTION 4.0 (CASE STUDY IN MEDAN ODH SOCIAL REHABILITATION CENTER)
}

\author{
Agussani $^{1^{*}}$, Emilda Sulasmi $^{2}$ \\ ${ }^{1}$ Universitas Muhammadiyah Sumatera Utara, Indonesia,e-mail:agussani@umsu.ac.id, \\ ${ }^{2}$ Universitas Muhammadiyah Sumatera Utara, Indonesia, e-mail: emilda@umsu.ac.id \\ *Corresponding Author

(C) 2021 by the authors. Submitted for possible open access publication under the terms and conditions of the Creative Commons
Attribution-ShareAlike 4.0 International License-(CC-BY-SA) (https://creativecommons.org/licenses/by-sa/4.0/)
do DOI : bttp:// dx.doi.ong/10.30983/islam_realitas.v7it.3789
\begin{tabular}{|l|c|c|}
\hline Submission: 23 December 2020 & Revised: 21 July 2021 & Published: 31 July 2021 \\
\hline
\end{tabular}

\section{Abstract}

This article aims to explain the challenge professional social workers in order to empower the community based on their license. The method used in this study is qualitative method with the study in ODH Social Rebabilitation Center "Babagia" Medan. This article found that the challenge of professionalism of technology-based social workers is internally related to using digital communication facilities. This can be overcome by training and mentoring and making technological innovations to strengthen social work in community empowerment. This article contributes the necessary knowledge that social workers must be civilized with information technology in today's digital age to support social workers' professionalism by using a dualistic approach in industrial revolution 4.0 towards the Society 5.0 revolution. Regarding the Certificate, it was found that certification is relevant to the professionalism of Social workers in Indonesia, especially social workers in the Center for The Development of Functional Positions of Social Workers and Social Extension, The Ministry of Social Affairs, and the Social Rehabilitation Center ODH "Bahagia" Medan.

Keywords: Professional Social Worker, Industrial Revolution 4.0, Social Rehabilitation Center ODH "Babagia" Medan

\begin{abstract}
Abstrak
Artikel ini bertujuan untuk menjelaskan tantangan pekerja sosial profesional dalam rangka melakukan pemberdayaan masyarakat berdasarkan lisensi yang dimiliki. Metode yang digunakan dalam penelitian ini adalah metode kualitatif dengan studi pada Balai Rehabilitasi Sosial ODH "Bahagia" Medan. Artikel ini menemukan bahwa bentuk tantangan profesionalisme pekerja sosial berbasis teknologi adalah secara internal berkenaan dengan kemampuan pemanfaatan sarana komunikasi digital, ini dapat diatasi dengan pelatihan dan pendampingan serta melakukan inovasi teknologi guna memperkuat kerja sosial dalam rangka pemberdayaan masyarakat. Artikel ini memberi kontribusi pengetahuan penting bahwa ternyata pekerja sosial harus beradabtasi dengan teknologi informasi di era digital saat ini, guna mendukung profesionalisme pekerja sosial dengan menggunakan dualistic approach pada era revolusi industri 4.0 menuju revolusi Society 5.0. Mengenai Sertifikat, ditemukan bahwa terdapat relevansi sertifikasi dengan profesionalisme pekerja Sosial di Indonesia, khususnya pekerja sosial di Pusat Pembinaan Jabatan Fungsional Pekerja Sosial dan Penyuluh Sosial, Kementerian Sosial dan Balai Rehabilitasi Sosial ODH "Bahagia” Medan.
\end{abstract}

Kata Kunci: Pekerja Sosial Profesional, Revolusi Industri 4.0, Balai Rehabilitasi Sosial ODH "Bahagia" Medan

\section{Background}

The social worker is a job that requires a set definition illustrates that it is no longer a side of skills, responsibility, and corporates ${ }^{1}$. The job or curative service that everyone can do, as commonly expected in Indonesia. ${ }^{2}$

1 Andari Soetji, 'Peran Pekerja Sosial dalam Pendampingan Sosial The Role of Social Workers in Social Assistance', Journal of Chemical Information and Modeling, 53.9 (2019), 1689-99.
2 Edi Suharto, 'Peran Pekerja Sosial Dalam Penanganan Masalah Sosial Global' Jakarta: Disampaikan pada Seminar "Isu-Isu Global dan Masalah Sosial Strategis yang Berpengaruh terhadap 
According to Rachmanto ${ }^{3}$, social worker professions are rare and not even attractive to some people due to a lack of understanding and socialization about social workers' profession as a profession of help to individuals, groups in need. Whereas in various countries, the social workers' profession has contributed very much, especially in community empowerment. ${ }^{4}$

Regulation of the Minister of Social Affairs Number 12 the Year 2017 concerning Social Worker Competency Standards accompanied by Attachment to Regulation of the Minister of Social Affairs Number 12 the Year 2017 concerning Social Worker Competency Standards containing Social Worker Competency Standards signed by Minister of Social Affairs Khofifah Indar Parawansa on July 10, 2017 states that the Social Worker Competency Standards are intended as a reference for Social Workers in carrying out social work practices and/or for certification bodies to test the competencies of Social Workers which include, knowledge, skills, professional attitudes of social work required to carry out social work practices ${ }^{5}$.

In explaining the profession of social workers in Regulation of the Minister of Social Affairs, it is explained that there are three types of social worker levels, namely Social Worker Assistants, Generali Social Workers, and Specialist Social Workers who have preventive, curative, rehabilitative, and development functions.

In Indonesia, the professions of social workers include involved in the Family of Hope Program (PKH), Family Welfare
Consultation Program (LK3), Child and Family Protection Program, Prosperous People's Assistance Program (Rastra), and so on.

Along with the technological advances that are currently sporadically moving progressively, it takes an increase in the ability of social workers who can be civilized in the face of global challenges, especially in the era of industrial revolution 4.0 and towards the industrial revolution 5.0 where the fight between culture and technology is increasing rapidly forming the character of an individualistic society, away from mutual values, and even towards a moral crisis.

Industrial Revolution 4.0 by quoting Kasali's opinion, there are six pillars of technology that are characteristic, namely: Internet of Things (IoT), Cloud Computing. Big Data Analytics, Artificial Intelligence, Super Apps, and Broadband Infrastructure 6 . From these six characteristics, there will also be challenges that must be faced by the community, namely aspects of knowledge, technology, economy, social, and politics ${ }^{7}$.

Resistance from technological advances ultimately puts culture and technology in two main vortexes, namely technology positioned as a tool to preserve culture and technology that creates new cultures in society. One of the cultures that emerged from the current era of technology is the culture of virtual solidarity that later became a trend and the development of information technology. Solidarity is a sense
Pembangunan Kesejahteraan Sosial" Departemen Sosial RI, 2004), 1.

3 Rachmanto, 'Pekerjaan Sosial Sebagai Suatu Profesi', Jurnal Informasi Kajian Permasalhan Sosial dan Usaha Kesejabteraan Sosial, Vol 7.No. 2 (2002), 34.

${ }^{4}$ Rachmanto.

5 Berita Negara Tahun 2017, '12 Tahun 2017 Tentang Standar Kompetensi Pekerja Sosial', 2018.
${ }^{6}$ Irfan Melilanny, 'Transformasi Praktik Pekerjaan Sosial Menuju Masyarakat 5.0', Sosio Informa, 6.02 (2020), 170.

${ }^{7}$ Hani Atun Mumtaha and Halwa Annisa Khoiri, 'Analisis Dampak Perkembangan Revolusi Industri 4.0 dan Society 5.0 Pada Perilaku Masyarakat Ekonomi (ECommerce)', Jurnal Pilar Teknologi : Jurnal Ilmiah Ilmu Ilmu Teknik, 4.2 (2019), 55-60 <https://doi.org/10.33319/piltek.v4i2.39>. 
of unity, togetherness, and sympathy from a group of people who have a certain similarity. ${ }^{8}$.

The research conducted by Santoso et $\mathrm{al}^{9}$. explained that the social work profession had transformed social services for the beneficiaries so that the social products created can be spread more widely and faster without the limitations of space and time; it showed that there had been an acceleration of the process of providing social services. However, compared to the business sector, the process of technology adoption in social work is much slower. Various changes that occur become challenges and opportunities for the social work profession and educational entities in the lot of social work as a printer institution for prospective social workers who have the chance to do social engineering in the community.

Similarly, research conducted by Andari ${ }^{10}$ that confirms that social workers carry out social assistance to improve the social functioning of individuals, families, communities to improve social welfare. Social workers as escorts implemented in empowerment require social service organization and professional performance is implemented in an integrated and integrative manner. Social workers as a profession lead to professionalism has a certified competence to have a reference work more productive and effectively oriented to the actual needs of society .

From the research below, it has not been seen how social workers as a profession that belongs to the category of professional social workers in the face of the industrial revolution era 4.0 towards society 5.0, for that reason, this research is important to do.
Based on these problems, this article becomes important to examine the challenges of social worker professionalism to empower the community in the era of industrial revolution 4.0, which is currently the global world is heading there. This needs to be done because social services is an activity that is very attached to the profession of social workers, and of course, the development of information and communication technology is an unavoidable transformational process and brings consequences to rethink the challenges and opportunities for the social work profession.

The method used to answer the problem is by collecting sources that examine social workers, both in the form of legislation and in the form of research results. Therefore, the data management from this article is done periodically by coding and tabulating it and analyzing the relevant materials with the focus of this article. This research was conducted on the object of study, namely Social Workers who are Social Workers in the Center for The Development of Functional Positions of Social Workers and Social Extension, The Ministry of Social Affairs and the Social Rehabilitation Center ODH "Bahagia" Medan (BRSODH) which is directly related to social workers in Indonesia. The informants consist of the Head of Pusbinjabfung, certified Social Workers, uncertified Social Workers and clients who are users of social worker services.

\section{Social Reality of Society in the Era of Industrial Revolution 4.0}

The era of disruption defines industrial revolution 4.0 or plural was originally a phenomenon that occurred in economics, especially in business. a Harvard Professor

Pekerjaan Sosial Seiring Perubahan Interaksi Sosial di Tengah Masyarakat Modern', Prosiding Penelitian dan Pengabdian kepada Masyarakat, 5.3 (2019), 272 <https://doi.org/10.24198/jppm.v5i3.20221>. ${ }^{10}$ Soetji. 
Bisinis calls it an innovative disruption. Disruptive itself is a condition when a business is required to continue to innovate following developments so that the business is not only to meet current needs but can anticipate future needs. ${ }^{11}$.

The industrial revolution is a phase measured by the development of world science and technology. It is called the digital revolution because of the proliferation of computers and recording from all fields. One of the uniqueness of the Industry 4.0 era is the application of artificial intelligence. Almost all fields occur automation with the presence of technological advances. Technological advances that successfully create changes to human activities in scale, scope, complexity, and transformation from previous life experiences.

The phenomenon of disruption does not only occur in the business world. However, it has expanded in other areas such as education, government, culture, politics, and law. For example, in the political field, political movements to gather time through the concentration of time have been replaced with social media-based movements. The government sector is also now challenged to implement bureaucracy effectively efficiently based on e-governance.

Industrial Era 4.0 is in an atmosphere of globalization that brings people to uncertain situations, and there are at least three things that indicate that globalization will be able to bring disaster to society. ${ }^{12}$, first globalization is based on the ideology of free-market fundamentalism that adheres to the myth of "the invisible hand" and antipathy to the state's role. As a result, the private market can perform its role more efficiently, which in turn encourages economic growth and social welfare through the mechanism of "seeping effects down." However, in reality, the "invisible hand" cannot regulate the market perfectly, especially in developing countries, due to information imperfections and market incompleteness. Indeed, under these conditions, state intervention is necessary to respond to imperfection and even market failure.

Second, globalization strengthens the hegemony of multinational or transnational corporations, and third, the dangers of globalization are not only caused by a load of neoliberalism ideology and capitalist interests of the world. Furthermore, it is supported by three important international institutions: the World Bank, the International Monetary Fund (IMF), and the World Trade Organization (WTO) that can grip the world.

In this era, the reality of society also encourages social change, which includes elements of material and immaterial culture, meaning that every element of social culture that is material and immaterial (spiritual) is also inclined to change. Also Kingsley Davis described as social change as changes that occur in society's structure and function so that it will be called a social change if the order and function in society are changed. For example, when there appears a union of workers or labor organizations that in capitalist society causes a change in relations between workers and employers which then implies also the change of economic or even political organization (in certain countries there are turned into political parties, for example, the labor party in England). ${ }^{13}$
${ }^{11}$ Banu Prasetyo and Danumi Trisyanti, 'Strategi Pembangunan Nasional Menghadapi Revolusi Industri 4.0', in Revolusi Industri 4.0 dan Tantangan Perubahan Sosial, 2019, IV, 22-27.

12 Edi Suharto, 'Peran Pekerja Sosial dalam Penanganan Masalah Sosial Global' Jakarta: Disampaikan pada Seminar "Isu-Isu Global dan
Masalah Sosial Strategis yang Berpengaruh terhadap Pembangunan Kesejahteraan Sosial "Departemen Sosial RI, 2004). 4.

13 Syamsidar, 'Dampak Perubahan Sosial Budaya Terhadap Pendidikan', Al-Irsyad Al-Nafs Jurnal Bimbingan Penyuluban Islam, 2.1 (2015), 83-92. 
Many argue that the tendency to change in society is a natural phenomenon as a result of social relations, and many experts argue, such as Rusmin ${ }^{14}$, Banu ${ }^{15}$ and Richar Hogart ${ }^{16}$ dan Paul $^{17}$ state that social change occurs as a result of changes that occur in elements that maintain balance in a society, such as economic, cultural, and technological, political, geographical and so on, which basically boils down to the conclusion that change is a circular and unbroken chain of events.

In terms of social change norms, then if the norm is based on the regularity of social life, social change, which is a change in the structure of society, occurs as a result of changes in social norms. When the norms in a community structure have changed, then the change in society has occurred. ${ }^{18}$

Environmental developments that occur at the domestic, regional, and global levels have implications for people's lives and color various life areas. Various issues in several fields that occur due to domestic, regional and global developments bring Indonesia to a critical situation, requiring handling where social workers can be a part.

Community and Sustainable Environment can be interpreted as a community order with the availability of resources, both material (SDA) and social (HR). People who can meet the needs of life without any shortcomings; communities that have a comfortable and safe environment; a society that has values of justice, values of kindness, virtue, and piety both individually and socially; communities that have a beautiful and beautiful living environment; communities that have a social environment that is full of peaceful, tolerant, respectful, empathy, and understanding each other.

Besides, the problem that also threatens the community is a problem that stems from environmental conditions. This problem can be caused by human beings themselves who do not have social sensitivity. There are various forms of this, including landslides, floods, and forest fires.

Along with the global market and postindustrialist symptoms include the condition and structure of the family and social life. Family structures tend to be nuclear and cosmopolitan families. Besides, postmodernist alienation is also characterized by alienation in people who are in busy people's lives. In such a society, the family's function is then linked to its main function, so that what happens is a deviation from family members such as juvenile delinquency and deviations of other social norms.

The reality of society in the era of revolution 5.0 is because of society's unpreparedness in responding to the current technological advances and the rapid influence of globalization, thus making people confused in responding to it. Modification of human life to achieve such transformation can be realized through four basic cultural structures: ethical constitution, aesthetics, work orientation, and technological knowledge ${ }^{19}$.

Organizational Psychology, Tenth Edition Paul, 2012, LIII < https://doi.org/10.1017/CBO9781107415324.004>. ${ }^{18}$ David Berry, Pokok-Pokok Pikiran dalam Sosiologi, ed. oleh Paulus Wirutomo (Jakarta: Raja Grafindo Persada, 2003), 43.

${ }^{19}$ Nunu Nurhanuddin and Hardi Putra Wirman, 'Social Theology: Re-Actualizing Cultural Values Into Society Transformation', Islam Realitas: Journal of Islamic \& Social Studies, $4.1 \quad$ (2018), 57 <https://doi.org/10.30983/islam_realitas.v4i1.652>. 


\section{The New Paradigm of Professional Social Workers; Stages to Social Welfare}

Related to the term of professional, Mendenhall Developing the concept of professionalism from the individual level includes five dimensions ${ }^{20}$, namely:

a. Dedication, which is reflected in professional dedication through the use of knowledge and proficiency. This attitude is an expression of total surrender to work. Work is defined as the purpose of life and not just as a tool to achieve goals. Total surrender is a personal commitment, and the primary compensation expected is spiritual satisfaction and then material satisfaction.

b. Social obligation (Social obligation) is a view on the importance of the profession's role and the benefits obtained both by the community and by professionals because of the work.

c. Independence (Autonomy demands), which is a view that a professional should make his own decisions without any pressure from the other party.

d. Belief in self-regulation is a belief that the authorities to assess professional work are fellow professions and not outsiders who do not have competence in their fields of science and work.

e. Relationship with fellow professions (Professional community affiliation) means using professional ties as a reference, including formal organizations and informal groups of colleagues as the primary source of work ideas. Through this professional bond, professionals build awareness of their profession.

Meanwhile, J.C Meister hinted at professionalism at the individual level covering 4 (four) dimensions ${ }^{21}$, namely:

a. Pride in work

b. Commitment to quality

c. Dedication to the interests of the client

d. Sincere desire to help

Social work is a practice-based profession and academic discipline that promotes social change and development, social cohesion, and community empowerment. Social justice principles, human rights, collective responsibility, and respect for diversification are central to social work. Supported by social work theories, social sciences, humanities, and indigenous knowledge, social work involves people and structures to overcome life's challenges and improve well-being.

Social workers have a complex scope of job roles, which has led to debates about which should come first. Their activities are often seen as activities that focus only on children and adults considered 'at at risk'. ${ }^{22}$

Social work as a profession has undergone significant changes, both internally and externally. This change is part of a larger ideological shift towards neoliberalism. ${ }^{23}$. The neo-liberalization of social work has become a result-oriented profession, information gathering, supervision that no longer relies on a critical and radical value base. However, social workers remain optimistic about the future and true to their core values.

The social work profession is broader than most disciplines concerning the variety and
20 Mendenhall W. dan R.J. Beaver, A Curse in Business Statistics, Thirth Edi (New York: PWS Ken Publishing Company., 1992). 231-234

21 J.C Meister, Corporate Universities in Building a World Class Work Force. (New York: McGraw-Hill, Inc, 1998). 111-113

22 Jo Moriarty, Mary Baginsky, and Jill Manthorpe, 'Literature Review of Roles and Issues within the Social Work Profession in England,' King's College London, March 2015 , <http://www.professionalstandards.org.uk/docs/defa ult-source/publications/research-paper/literaturereview-roles-and-issues-within-the-social-workprofession-in-england-2015.pdf?sfvrsn $=6>$.

${ }^{23}$ Janine Butler-Warke, Alice; Yuill, Chris; Bolger, 'The Changing Face of Social Work: Social Worker Perceptions of a Neoliberalising Profession,' Critical and Radical Social Work, Vol. 8.1 (2020), 59-75 <https://www.ingentaconnect.com/content/tpp/crs w/2020/00000008/00000001/art00005>. 
types of problems addressed by the arrangements in which the work occurs, the level of practice, the interventions used, and the population served.

Social workers can engage in various jobs ranging from hospitals, schools, clinics, police departments, public institutions, the court system to private practices or businesses. Social work practices require knowledge of human development and behavior. ${ }^{24}$

Rapid socio-cultural, economic, and political changes have implications for the social work profession. Similarly, the application of ISO applied in developed countries is a challenge that must be responded to. The social work profession must be encouraged continuously so that it can apply national and international standards. Therefore, education and training and standardization, and certification of social workers play a significant role in shaping the 'direction' and existence of the social work profession.

Social workers are professional activities to improve their ability to function socially and create community conditions that allow them to achieve goals. Siporin defines the style of social work practitioners as a factor that greatly influences therapeutics' effectiveness and is a way to express the creative arts of practitioners. The meaning and function of the style are made clear. The practitioner's general style is analyzed as a combination of elements of personal and professional style, responsive to the performance of artistic tasks in helping the client. The case presentation illustrates the specific style of social workers. The broader cultural influence of the practitioner's style also deserves to be recognized.
The widespread problems in modern society, such as differences in lifestyle, values, race, ethnicity, culture, religious identity, forcing social welfare efforts carried out by social workers are always responsive and willing to learn to understand what is happening in society. Thus, social workers need skills to realize and encourage the spirit and improve the ability of clients. Therefore, social workers can provide services under their intervention's objectives based on a "strengths perspective." 25

Therefore, there is a change in social welfare, which is a paradigm that comes not suddenly. The change has historical roots since Wilensky and Leabaux ${ }^{26}$ Introduced two social welfare concepts, namely the concept of social welfare based on 'residual' and social welfare based on 'institutional.' In America, it developed 'residual and developmental.'

Purwowibowo mentioned that the concept of social welfare experienced three stages of development in the midst of social change, namely the first stage, when the Poverty Law, namely Elizabeth Poor Law (1601), was introduced to provide social security in the form of assistance or assistance services to the poor in England, the second stage, social welfare in the context of the welfare state. In this case, the state provides social expenditure to its citizens to ensure minimum service standards for all its citizens, and the third stage, the concept of prosperous society (Welfare Society), which is based on the concept that the aspirations that come from the community regarding efforts to maximize individual development. ${ }^{27}$

The Social Worker Profession is time to get a greater place and space in solving the nation's problems, where social problems are as
24 Caroline F. Ware, 'The Role of the Social Worker in Community Development,' International Social Work, $10.4 \quad$ (1967), $13-17$ <https://doi.org/10.1177/002087286701000402>.

25 Purwowibowo, 'Perkembangan Konsep Kesejahteraan Sosial dan Pekerja Sosial Profesional di
Era Global', Jurnal Ilmu Kesejabteraan Sosial Humanitas, 1.2 (2019), 64-75.

26 Wickenden Elizabeth, Social Welfare in a Changing World (Washington DC: University Press, 1965), 213.

27 Purwowibowo. 
important as other problems that require extra attention and solutions, especially in the era of Industrial Revolution 4.0 towards the Social Revolution 5.0 concerning some of the following functions; First, Enabling or Facilitation Function. Function as Strengthener. Second, this function is related to education and training to strengthen community capacity (Capacity Building), Function as a Protection. Third, this function is related to the interaction between the companion and external institutions for the sake of the community he accompanied and the Function as a Supporting Giver. Fourth, Based on the practical application of skills that support positive programs from the community.

\section{Social Worker Practice License at $\mathbf{O D H}$ Social Rehabilitation Center "Bahagia" Medan}

Center for Development of Functional Position of Social Workers and Social Extension as Echelon II work unit within the Social Welfare Education and Research Agency, Ministry of Social Affairs, based on Regulation of the Minister of Social Affairs No. 86/HUK/2010 concerning Organization and Work Procedure of the Ministry of Social Affairs has the task of carrying out policy formulation and coordination as well as the implementation of the field of development of functional positions of social workers, social counselling, granting accreditation and Certification for social workers.

Certification is given to a social worker as a form of recognition of the qualifications possessed by social workers. With the recognition of the qualifications it has, a social worker will apply for a practice permit as a social worker to the state through the Ministry of Social Affairs. Practice permits are granted to social workers individually. By having an applicable license, a social worker has the authority to perform his role as a social worker.

A practice permit issued to a social worker indicates a mandate from the state to practice social work. In the process of issuing a practice permit, Regulation of the Minister of Social Affairs number 03 of 2015 mandates that social workers can apply for a practice permit to the Minister of Social Affairs through the LSPS. A vital component that must be approved in applying for this practice permit is the recommendation of the professional association. This certificate is given that the coaching and supervision of social workers who have competency certification and practice permits are carried out by professional associations. This guidance and supervision are indispensable for social workers to ensure that the practices are carried out correctly and achieve the expected quality of service. ODH Social Rehabilitation Center "Bahagia" Medan is a Technical Implementation Unit (UPT) of the Ministry of Social Affairs under and responsible to the Directorate General of Social Rehabilitation. ODH Social Rehabilitation Center "Bahagia" Medan is a Technical Implementation Unit (UPT) of the Ministry of Social Affairs that conducts Social Rehabilitation for people with $\mathrm{HIV}^{28}$

BSOD "Bahagia" Medan is under and directly responsible to the Director-General of Social Rehabilitation. BRSODH "Bahagia" working area in Medan includes Aceh, North Sumatra, West Sumatra, Bengkulu, Bangka Belitung, Lampung, South Sumatra, Jambi, Riau Islands, Riau, South Kalimantan, East Kalimantan, Central Kalimantan, West Kalimantan, and North Kalimantan.

To know the relevance of Certification to the professionalism of Social workers in Indonesia, especially social workers in the Center for Development of Functional 
Positions of Social Workers and Social Extension, the Ministry of Social Affairs and The Social Rehabilitation Center ODH "Bahagia" Medan required data collection techniques with documentation of various forms of data needed as qualitative research support. Data analysis related to the Relevance of Certification and Professionalism of Social Workers in Indonesia in this study refers to the framework of research and literature that supports $i^{29}$.

The source to review the credibility of the data is done by checking the data obtained through several sources. In this case, to test the credibility of data on the Relevance of Certification and Professionalism of Social Workers in Indonesia.

The results of this study showed the relevance of social worker certification with the dimension of dedication, especially social workers at ODH "Bahagia" Medan Social Rehabilitation Center.

This is useful for formulating policies related to the application of professional dedication through the use of knowledge and skills possessed by social workers, and can also be used as an evaluation material in the application of the use of knowledge and skills possessed by social workers in performing services to clients of social welfare service users.

The results of the analysis also show the relevance of social worker certification with the dimension of professionalism, namely social obligation; it can be helpful to see how vital the role of social workers is for society and other professionals, and to be able to see how much certification of social workers influences society and other professionals. The provision of professional certificates for the public will guarantee the quality of social worker services, and for other professionals will show an equal professional image. Based on this fact, it is expected that all social workers will follow the social worker certification process ${ }^{30}$.

Furthermore, the dimension of professionalism is independence (autonomy demand), and its relevance to the certification of social workers are expected to be able to open independent practices so that they can make their own decisions without pressure from other parties (government, clients, those who are not members of the profession)

The analysis results on the dimension of belief in professional regulation (belief in selfregulation) and its relevance to the certification of social workers show that in conducting social work practices, certified social workers are more confident in regulations that protect their practices. Because certification is proof of recognition by the authorized institutions of the competence and ability of social workers, this kind of thing is also perfect for social workers because it makes them feel valued, so it can indirectly affect the client and the image of the institution ${ }^{31}$.

The results of the analysis on the relationship with fellow professions (professional community affiliation) with relevance to the certification of social workers show that the certification will encourage the importance of the existence of bonds that can be used as a forum for exchanging ideas and media for professional development and to protect its members so that it will awaken the awareness of the social worker profession. This can undoubtedly strengthen the existence of the social worker profession bond itself.

The results of the analysis on the dimensions of pride in the work and its relevance to the certification of social workers show that certification makes social workers
${ }^{29}$ Sri Wibowo (Head of BRSODH "Bahagaia" Medan), Interview \{Monday, 4 January 2021\}

30 BRSODH Medan, Laporan Tabunan (Medan: BRSODH Press, 2020), p. 14.
${ }^{31}$ BRSODH Medan, Dokumen Laporan Tabunan, p. 18. 
feel legally recognized to make them moreproud of their work. Based on this, it is expected that the influence of certification will be positive for all institutions related to the social work profession. This will undoubtedly affect both the social work profession, the client, the community, and the image of the social welfare institutions in which social workers work.

Regarding the dimensions of commitment to quality and relevance to social worker certification, the analysis results in the previous chapter show that one of the commitments of social workers to the quality of their services is to follow the certification. With certification, social workers can assure that they are competent and can provide assurance on the quality of their services. This can positively impact the client and the image of the institution in which they work.

Related to the dimension of dedication to the interests of the client and its relevance to the certification of social workers, according to the results of the analysis, it shows that certification is one way for social workers to dedicate their profession to the benefit of the client. Because with certification, clients get a guarantee of legal certainty over the quality of service from social workers.

By following the certification, social workers can help clients who want to get quality social welfare services.

\section{Professionalism Challenges of Social Workers in the Era Revolution 4.0}

In every job, the professional aspect becomes an important point, especially in today's modern era. Therefore, professionals demand workers perform consistently with 'certain professional standards.'

The profession of social workers today has not received appreciation from the wider community proportionately. This may be because the existence of this profession has not been felt benefits by the community. Many public members, even high-ranking state officials, do not know what exactly social workers are dealing with. There is currently extensive development in this profession, namely the emergence of a generalist-generalist social work approach in the framework of community empowerment.

The principles of empowerment from a social work perspective are: Every problem is seen as a common challenge that must be faced; Orientation to simultaneous problems with the orientation to the source of strength; All processes are intended to produce the best in the future; The relationship between actors is collaborative; and Positions between actors in the form of partnerships.

For social workers' profession in carrying out their profession, there are professional standards that can be used as indicators for social workers in carrying out their profession daily. In addition to professional standards can also help practitioners when faced with ethical dilemmas and can also help supervisors of institutions and other administrative personnel evaluate their workers' performance. ${ }^{32}$

The professional standard is covering three objectives-first, internal oversight and accountability mechanisms for the profession. Clients who have concerns about their interactions with social workers can bring complaints to professional committees about investigations. The committee may request a series of sanctions, including the revocation of member vessels in professional associations.

Second, the standard of care is a measure of quality control for exercise. In countries where social workers are licensed or registered, these standards can help regulators hear client complaints against them to determine whether sanctions should be imposed in the event of a violation.
32 Srinika Jayaratne, Tom Croxton, and Debra Mattison, 'Social Work Professional Standards: An
Exploratory Study,' Social Work, 42.2 (1997), 187-99 <https://doi.org/10.1093/sw/42.2.187>. 
Third, the standard of care is the criterion by which the law will judge social workers. While not all legal action against social workers involves standards of care ${ }^{33}$.

The initial spirit of technological advancement was to facilitate human life. Since the invention of the machine and the beginning of the era of automation has made production more multiple and cut the time and costs incurred. However, in the end, all these conveniences have a big human impact because it makes the use of human power significantly reduced. ${ }^{34}$. As a result, there has been an increase in the number of unemployed. Right at this point, it is necessary to have a development paradigm that improves human abilities in the field of technology and needs to improve its own human mentality.

The change in social welfare concept towards institutional and developmental concepts also has a first-line function in industrial society. Therefore, the paradigm 'Social welfare' must be changed. There are seven components or pillars of the social welfare paradigm that, according to Romanyshyn (1989), need to be socialized, namely, First, the Residual Concept Becomes Institutional. In the residual paradigm of placing social welfare programs outside the normal institutions of society. Second, the Concept of Charity Becomes the Concept of The Rights of Citizens. This change in concept is a very long historical process. Third, the Concept of Special Becomes Universal. For the layperson, social welfare is often defined by a special program intended for the poor. Fourth, The Minimum Concept Towards Optimum. The new paradigm of social welfare should move from the limited assertion that only minimal resources are provided to individuals who have problems: fifth, the Concept of Individual Reformation to Social Reform. The old paradigm departs from the assumption that social welfare is formed and allocated to individuals who experience moral decline: sixth, the Concept of Voluntary Service Towards Public Service. Public responsibility for social welfare services is truly a 19th and early 20th-century tradition: seventh, The Concept of Welfare for the Poor and the Concept of Prosperous Society for the Rich. In the concept of welfare society, all social institutions must be evaluated critically in the sense of the extent of their contribution in terms of maximizing development for the benefit of individuals and society at large.

The presence of the era of industrial revolution 4.0 that offers new literacy, namely data, technology, and human literation, as a new thesis of the digital technology era, since 2018 appeared "anti-thesis" from Japan that better upholds "human" in addition to the emergence of data and technology revolution. According to japan's Cabinet Office, Society 5.0 is defined as a human-centered society that balances economic progress with social problem solving through a system that strongly integrates virtual space and physical space. ${ }^{35}$.

As a developed country with high-tech capabilities, Japan does not mean it does not have "internal" problems, including a smaller birth rate, a smaller number of productive age populations, and an increasingly elderly population. With such unfavorable demographic conditions, the use of technology is certainly one of the options. But how technology is utilized without degrading the values of Japanese society is close, that later became the foundation of the concept formulated Society $5.0^{36}$.
33 Jayaratne, Croxton, and Mattison.

34 Bell Daniel, The Coming of Post Industrial Society (New York: Basic Books, 1976), 31.

${ }^{35}$ Nuning Zaidaha and others, 'Pembelajaran Seni Multikultural Menghadapi Konstruksi Masyarakat 5.0
Pada Era Vuca', Seminar Nasional Pascasarjana 2019, 2019.

$$
{ }^{36} \text { Mumtaha and Khoiri. }
$$


Society 5.0 focuses on life balance despite being based on technological advances. A working system that transforms digital technology but focuses not only on its technology but also the spirit of spirituality and humanity in utilizing technology, thus achieving a balance between cyberspace and the physical world. Muller et al. in Pilloni stated that Industry 4.0's attention is too focused on economic and technological dimensions. Its social impact must also be taken into account and, obviously, the impact of technology. ${ }^{37} \mathrm{~A}$ simple example is in education, that technology in the field of education should not change the role of educators in teaching moral education and nudity to learners. There are five elements in Society 5.0, namely: Emotional elements, intellectual elements, physical elements, social elements, and spiritual elements. The five elements are intertwined with each other in a balance.

The concept of Society 5.0 is expected to minimize the negative impact of robotics and artificially intelligent technology so as not to master human life without control, but human actors who master and control robotics and artificially intelligent technology. Thus, Society 5.0 is a fores looking forward to organizing an ideal public life, in response to the industrial revolution 4.0, which is feared to degrade humans' role due to dependence on advances in robotic technology and artificial intelligence. With Society 5.0, it is expected that there is a balance of life between the use of technology and the quality of human life that is more human. ${ }^{38}$
Actually, the concept of revolution 4.0 and Society 5.0 does not have much difference. It is just that the concept of Society 5.0 focuses more context on humans. If the Industrial Revolution 4.0 uses artificial intelligence as the main component in making changes in the future, then Society 5.0 uses modern technology to rely solely on humans as its main component. Society 4.0 allows us to access as well as share information on the internet. Society 5.0 is an era where all technology is part of man himself. The Internet is not just to share information but to live life ${ }^{39}$.

Society 5.0 is an evolutionary stage of human society, starting with Society 1.0 , which begins with human society's life by hunting to meet its needs. Furthermore, Society 2.0 has opened agricultural fields and plantations as the main food source. ${ }^{40}$ Then Society 3.0 is characterized by industrialization in all fields. In Society 5.0, there are advances in information technology and the internet to connect. Society 5.0 focuses on utilizing technology for humankind's welfare by controlling the negative impact it causes.

Society 5.0 is parallel capable of achieving economic development while providing solutions to social problems. Therefore Society 5.0, although it relies on technological advances but is focused and human-centered. The principle in Society 5.0 is that anyone can enjoy a high quality of life and can enjoy a prosperous life. ${ }^{41}$

In this situation, professional social workers are faced with a variety of challenges that require the professionalism of social workers. The urgent thing to do is to certify social
37 Virginia Pilloni, 'How Data Will Transform Industrial Processes: Crowdsensing, Crowdsourcing and Big Data as Pillars of Industry 4.0', Future Internet, $10.4 \quad$ (2018), 67-83 <https://doi.org/10.3390/fi10030024>.

38 Sandro Serpa and others, 'Digital Society and Social Dynamics', Digital Society and Social Dynamics, September, 2020, 31-44 <https://doi.org/10.14738/eb.17.2020>.
39 Carlos Miguel Ferreira and Sandro Serpa, 'Society 5.0 and Social Development', Preprints, 1.November (2018), 1-6 <https://doi.org/10.20944/preprints201811.0108.v1 $>$.

40 Hitachi, Society 5.0 A People-centric Super-smart Society (Japan: Springer, 2018), 45.

${ }^{41}$ Serpa and others. 
workers. For a profession, standardization of competencies that become the basis for carrying out the next step, namely certification is for Articulation and professional advocacy; Quality demands (standards); Accountability demands (principles) and; Monopoly of the field of work and restrictions on market supply. ${ }^{42}$

The challenges of globalization and increasing the quantity and quality of social problems require reliable human resources that have knowledge, skills \& attitude to improve the quality of service. Social Work Human Resources plays an important role in responding to these changes. The level and quality of social services are determined by the quality of Human Resources Social Work.

Especially in the era of industrial revolution 4.0 and facing the current era of society 5.0, social workers must have Social Welfare Human Resources' qualifications and competencies reflected from the competencies of knowledge, skills, and values with the formula Knowledge + Skills + Values $=$ Competence.

Therefore, today's professional social workers' most fundamental challenge is to carry out their duties and functions effectively as professional social workers, and then the social work education system needs to be fundamentally reorganized. Reorganization can include curriculum, educational process, teaching staff, field practice supervisors, libraries, textbooks, or social work laboratories where students practice field.

For the completeness of standardization and certification of social work, it is necessary to review and follow up on matters related to granting licenses or licenses of practice, assessors, and competency tests for professional social workers.
Professional social workers should also be able to take advantage of developments in information technology because the problems of the clients they handle are actually not far from what their clients consume information. Therefore, these information media play a vital role in shaping one's mind, which will shape his actions and life as a whole.

However, social workers' use of information as part of relief efforts for their clients is not without difficulties. Ethical dilemmas seem to be the most important issue in using information technology as a means of assistance for clients. The social work code of conduct requires professionals in this field to respect client privacy. Social workers are forbidden from forcing clients to pass on information they do not wish to convey.

In fact, social workers in the era of Industrial Revolution 4.0 and facing the Era of Society 5.0 social workers should be able to use a dualistic approach that conventionally handles clients and can also be done digitally.

\section{Conclusion}

Social change of society in the era of industrial revolution 4.0 and facing society's 5.0 revolution is actually a tough challenge for social workers. The biggest challenge that must be faced is social workers' ability to utilize the advancement of science and technology without neglecting the values of humanity with the aim of prospering society. Therefore, professionalism is required that is supported by competence based on the standard criteria of social workers. This is necessary to improve the competence of social workers by reformulating the educational curriculum of social workers. The most important thing is to be reviewed and acted upon on matters related to granting licenses or licenses of practice,
42 Agustus Fajar and Rudi Saprudin Darwis, 'Tantangan Kiprah Pekerja Sosial Profesional di Indonesia', Prosiding Penelitian dan Pengabdian Kepada
Masyarakat, $\quad 4.1$

<https://doi.org/10.24198/jppm.v4i1.14207>.
29 
assessors, and competency tests for professional social workers.

\section{References}

\section{Books}

Berita Negara Tahun 2017, '12 Tahun 2017 Tentang Standar Kompetensi Pekerja Sosial', 2018

BRSODH Medan, Dokumen Laporan Tabunan (Medan: BRSODH Press, 2019)

, Laporan Tahunan (Medan: BRSODH Press, 2020)

Daniel, Bell, The Coming of Post Industrial Society (New York: Basic Books, 1976)

David Berry, Pokok-Pokok Pikiran dalam Sosiologi, ed. by Paulus Wirutomo (Jakarta: Raja Grafindo Persada, 2003)

Elizabeth, Wickenden, Social Welfare in a Changing World (Washington DC: University Press, 1965)

Hitachi, Society 5.0 A People-Centric Super-Smart Society (Japan: Springer, 2018)

J.C Meister, Corporate Universities in Building a World Class Work Force. (New York: McGraw-Hill, Inc, 1998)

Mendenhall W. dan R.J. Beaver, A Curse in Business Statistics, Thirth Edi (New York: PWS Ken Publishing Company., 1992)

\section{Journals}

Butler-Warke, Alice; Yuill, Chris; Bolger, Janine, 'The Changing Face of Social Work: Social Worker Perceptions of a Neoliberalising Profession', Critical and Radical Social Work, Vol. 8.1 (2020), 5975

Fajar, Agustus, and Rudi Saprudin Darwis, 'Tantangan Kiprah Pekerja Sosial Profesional di Indonesia', Prosiding Penelitian dan Pengabdian Kepada Masyarakat, $4.1 \quad$ (2017), 29 <https://doi.org/10.24198/jppm.v4i1.1 4207>

Ferreira, Carlos Miguel, and Sandro Serpa, 'Society 5.0 and Social Development', Preprints, 1.November (2018), 1-6
< https://doi.org/10.20944/preprints20 1811.0108.v1>

Hoggart, Richard, 'The Uses of Literacy', The Uses of Literacy, 2017, 1-320 $<$ https://doi.org/10.4324/9781351302 043>

Jayaratne, Srinika, Tom Croxton, and Debra Mattison, 'Social Work Professional Standards: An Exploratory Study', Social Work, $42.2 \quad$ (1997), 187-99 $<$ https://doi.org/10.1093/sw/42.2.187 $>$

Jo Moriarty, Mary Baginsky, and Jill Manthorpe, 'Literature Review of Roles and Issues within the Social Work Profession in England', King's Collage London, March, 2015, 35

Melilanny, Irfan, 'Transformasi Praktik Pekerjaan Sosial Menuju Masyarakat 5.0', Sosio Informa, 6.02 (2020), 170

Mumtaha, Hani Atun, and Halwa Annisa Khoiri, 'Analisis Dampak Perkembangan Revolusi Industri 4.0 Dan Society 5.0 Pada Perilaku Masyarakat Ekonomi (ECommerce)', Jurnal Pilar Teknologi: Jurnal Ilmiah Ilmu Ilmu Teknik, 4.2 (2019), 55-60 $<$ https://doi.org/10.33319/piltek.v4i2. 39>

Nurhanuddin, Nunu, and Hardi Putra Wirman, 'Social Theology: ReActualizing Cultural Values Into Society Transformation', Islam Realitas: Journal of Islamic \& Social Studies, 4.1 (2018), 57 $<$ https://doi.org/10.30983/islam_realit as.v4i1.652>

Pilloni, Virginia, 'How Data Will Transform Industrial Processes: Crowdsensing, Crowdsourcing and Big Data as Pillars of Industry 4.0', Future Internet, 10.4 (2018) $<$ https://doi.org/10.3390/fi10030024>

Purwowibowo, 'Perkembangan Konsep Kesejahteraan Sosial Dan Pekerja Sosial Profesional di Era Global', Jurnal Ilmu Kesejabteraan Sosial Humanitas, 1.2 (2019), 64-75

Rachmanto, 'Pekerjaan Sosial Sebagai Suatu Profesi', Jurnal Informasi Kajian 
Permasalhan Sosial dan Usaha Kesejabteraan Sosial, Vol 7.No. 2 (2002), 34

Serpa, Sandro, Carlos Miguel Ferreira, Maria José Sá, and Ana Isabel Santos, 'Digital Society and Social Dynamics', Digital Society and Social Dynamics, September, 2020

<https://doi.org/10.14738/eb.17.2020

$>$

Soetji, Andari, 'Peran Pekerja Sosial dalam Pendampingan Sosial The Role of Social Workers in Social Assistance', Journal of Chemical Information and Modeling, 53.9 (2019), 1689-99

Syamsidar, 'Dampak Perubahan Sosial Budaya Terhadap Pendidikan', Al-Irsyad Al-Nafs Jurnal Bimbingan Penyuluban Islam, 2.1 (2015), 83-92

Tumanggor, Rusmin, 'Pemberdayaan Kearifan Lokal Memacu Kesetaraan Komunitas Adat Terpencil', Jurnal Penelitian dan Pengembangan Kesejabteraan Sosial, 12.01 (2007), 1-17

Ware, Caroline F., 'The Role of the Social Worker in Community Development', International Social Work, 10.4 (1967), 1317

<https://doi.org/10.1177/0020872867 01000402>

Warto, Warto, 'Budaya Gadget di Pondok Pesantren Mitra IAIN Purwokerto', IBDA : Jurnal Kajian Islam dan Budaya, $15.2 \quad$ (2018), 346-64 <https://doi.org/10.24090/ibda.v15i2. 2017.pp346-364>

\section{Others}

Paul M. Muchinsky, Inovasi Pendidikan Suatu Analisis terbadap Kebijakan Baru Pendidikan, Psychology Applied to Work: An Introduction to Industrial and Organizational Psychology, Tenth Edition Paul, 2012, LIII <https://doi.org/10.1017/CBO978110 7415324.004>

Prasetyo, Banu, and Danumi Trisyanti, 'Strategi Pembangunan Nasional Menghadapi Revolusi Industri 4.0', in Revolusi Industri 4.0 dan Tantangan Perubahan Sosial, 2019, IV, 22-27

Santoso, Meilanny Budiarti, Dessy Hasanah Siti Asiah, and Moch Zainuddin, 'Tantangan Praktik Pekerjaan Sosial Seiring Perubahan Interaksi Sosial di Tengah Masyarakat Modern', Prosiding Penelitian dan Pengabdian Kepada Masyarakat, $5.3 \quad$ (2019), 272 <https://doi.org/10.24198/jppm.v5i3.2 0221>

Suharto, Edi, 'Peran Pekerja Sosial dalam Penanganan Masalah Sosial Global' (Jakarta: Disampaikan pada Seminar "Isu-Isu Global dan Masalah Sosial Strategis yang Berpengaruh terhadap Pembangunan Kesejahteraan Sosial Departemen Sosial RI, 2004)

Zaidaha, Nuning, M. Jazuli, Darsono, and Sunarto, 'Pembelajaran Seni Multikultural Menghadapi Konstruksi Masyarakat 5.0 Pada Era Vuca', Seminar Nasional Pascasarjana 2019, 2019 